\title{
RUSSIAN FINANCIAL MARKETS IN MAY 2015
}

\author{
E.Gorbatikov, E.Khudko
}

The dynamics of the MICEX Index saw no drastic movements last month ${ }^{1}$, avaraging 1650 index points, with a 1.2\% fall at month's end. The rest of the MICEX Sector Indices, except the MICEX Telecommunications Index, demonstrated negative dynamics too. The MICEX daily average turnover kept shrinking and amounted to $R b 30.4 b n$. The situation in the Russian domestic corporate bond market in June was relatively normalized. The key market indicators such as the market volume and the corporate bond market index saw moderately positive dynamics; investors' activity remained high in the primary and secondary markets (particularly in the financial segment). Growth in the weighted average yield rate of bond issuances was an adverse trend. The problem with the failure to meet obligations to bondholders is still there.

\section{The dynamics of Russia's}

\section{stock market basic structural indices}

The MICEX Index in the period between 26 May 2015 and 25 June 2015 was relatively stable, deviating by not more than $2.5 \%$ from the monthly average of $1650^{2}$ index points. After a short sinking to 1609 index points at the very end of May, the Index rebounded rapidly to its average and then stayed within the same range until the very end of the reporting period. The Index reached 1632 index points on 25 June, down $1.2 \%$ from the value seen on 26 May 2015. Neither did Brent oil futures prices see any strong fluctuations: the price as of the beginning of the reporting period ( $\$ 63.9$ per barrel) was equal to the average price in the following month, with a $3.5 \%$ maximum deviation from the average price (the price went up to $\$ 66.2$ per barrel on 10 June 2015). The oil price dropped by $1.1 \%$ at month's end.

Almost all of the blue chips showed again a small negative ROE. VTB's shares, which took the lead last month, sank deeper than other blue chips, with a

1 In the period between 26 May 2015 and 25 June 2015.

2 The data hereinafter are MICEX closing data.

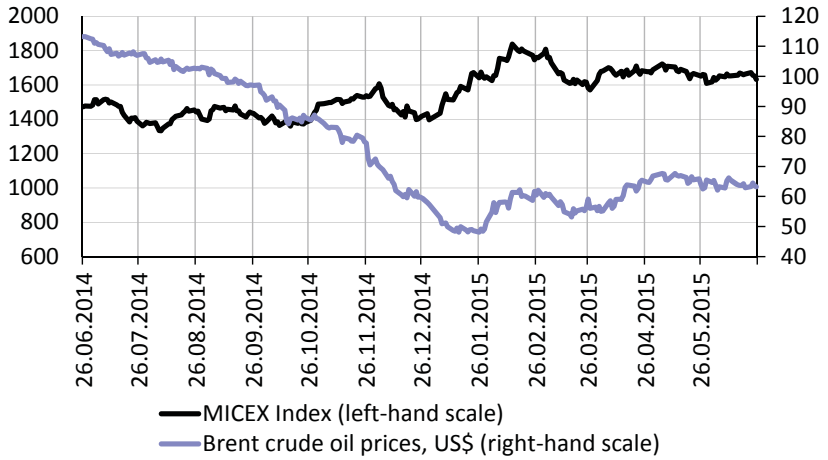

Source: RBK Quote, Finam.

Fig. 1. The dynamics of the MICEX Index and futures prices of Brent crude oil in the period between 26 June 2014 and 25 June 2015

monthly loss of 5.6\%. LUKOIL's shares saw almost the same loss (-5.3\%). The shares of Rosneft, Sberbank and Gazprom lost slightly less, 3.6\%, 3.8\% and $2.7 \%$, respectively. Surgutneftegaz was one of the few highly liquid companies which saw their shares grow substantially. Surgutneftegaz's preferred shares increased almost $7 \%$.

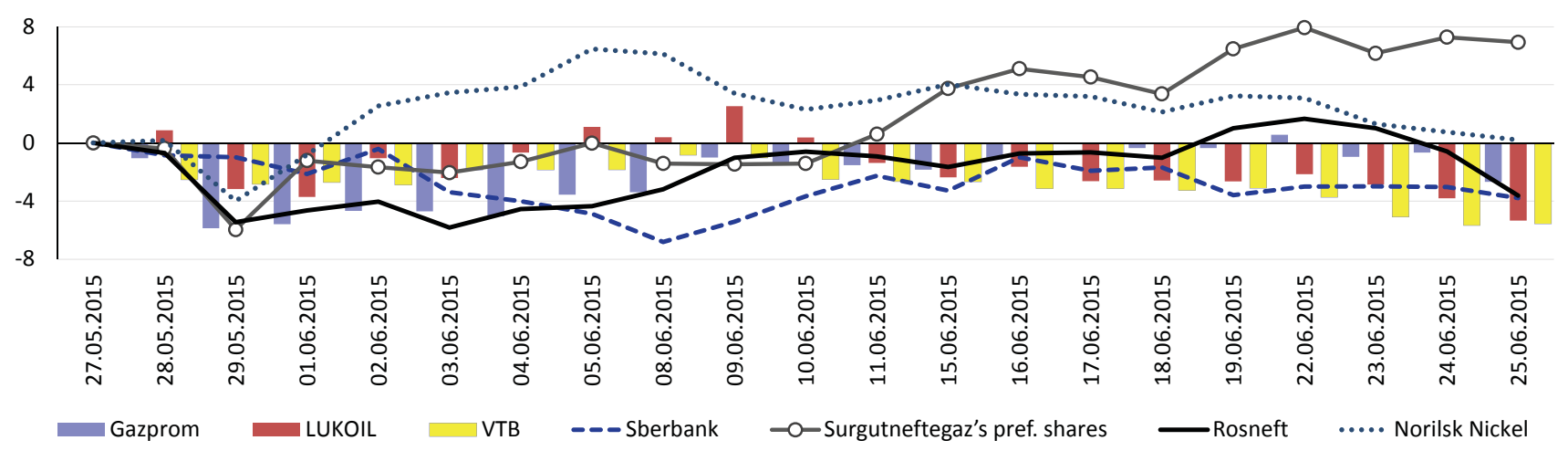

Source: RBK Quote, author's estimates.

Fig. 2. Growth rates of highly liquid Russian stocks in the Moscow Exchange in the period between 27 May 2015 and 25 June 2015 
The top-3 leaders in annual ROE remained the same as the previous month. VTB, with more than a $80 \%$ annual growth, remained at the top of the list followed by Surgutneftegaz and Norisk Nickel, respectively. The shares of Gazprom and Rosneft saw a small decline annually, whereas Sberbank's shares faced an annual loss of more than $15 \%$.

Thanks to almost $15 \%$ hike in Rostelecom's shares ${ }^{1}$, the MICEX Telecommunications Index took the lead in growth (up 1.4\%) among the MICEX Sector Indices in the previous month. Other MICEX Indices decreased slightly by $1 \%$ to $4 \%$. The MICEX Energy Index and Transport Index sank deeper than other indices, 4.0\% and $4.7 \%$, respectively.

The Moscow Exchange's (MOEX) turnover kept shrinking, with a total turnover running at $\mathrm{Rb} 669.0 \mathrm{bn}$ in the period between 26 May 2015 and 25 June 2015, being equal to $\mathrm{Rb} 30.4 \mathrm{bn}$ daily average turnover, i.e. down $2.8 \%$ in comparison with the previous month, and down $16.4 \%$ from the corresponding period last year.

Sberbank's shares remained the unbeatable leader in total turnover despite a $2.8 \%$ loss from the previous month, but still contributing almost one fourth (24.8\%) to MOEX turnover, whereas Gazprom and VTB account for respectively $13.2 \%$ and $11.8 \%$. It is worthwhile noting that VTB's shares have almost tripled in MOEX turnover during the past three months. Therefore, the top-3 leaders in turnover together account for $49.9 \%$ of MOEX turnover, whereas LUKOIL, Surgutneftegaz, Norilsk Nickel, Rosneft, Magnit together account for another $26.6 \%$ of the turnover.

According to the data of the Emerging Portfolio Fund Research (EPFR), Russia-focused mutual funds began to see an inflow of investment capital (up $\$ 10.1 \mathrm{~m}$ within a week) in the second half of May 2015 and then there were three weeks of capital outflows.

1 http://www.vedomosti.ru/technology/articles/2015/06/11/596117-rostelekom-podorozhal-pochti-na-20-za-pervuyudekadu-iyunya

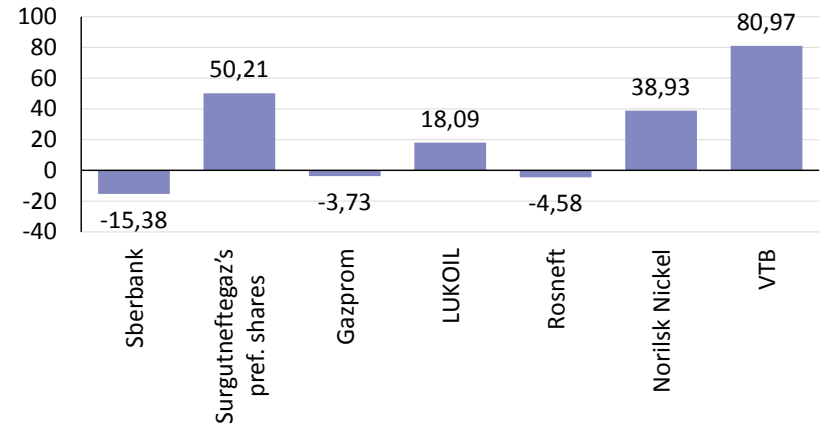

Source: RBK Quote, author's estimates.

Fig. 3. Growth rates of highly liquid Russian stocks in the Moscow Exchange in the period between 26 June 2014 and 25 June 2015

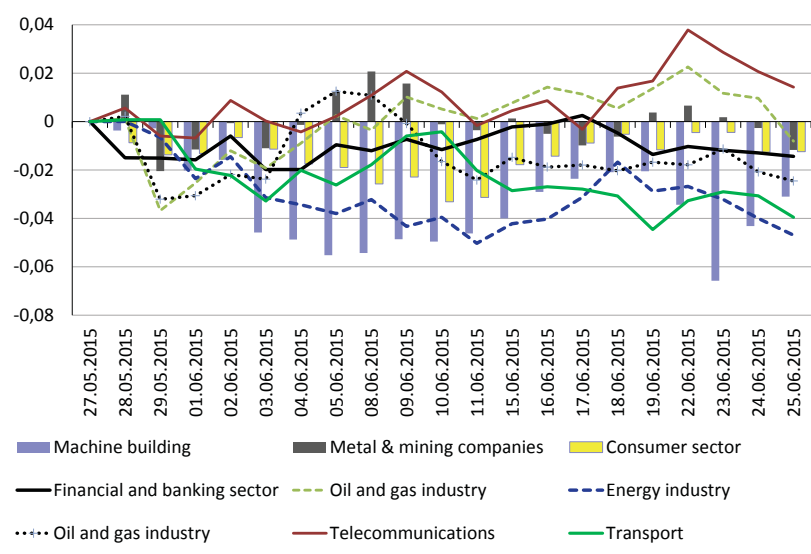

Source: RBK Quote, author's estimates.

Fig. 4. Growth rates in various sector stock indices in the Moscow Exchange in the period between 27 May 2015 and 25 June 2015

In the period between 21 May and 10 June 2015, Russia-focused mutual funds saw capital outflows, a total of $\$ 161.5 \mathrm{~m}$. The aggregate capital inflows from the beginning of 2015 till 10 June were nonetheless positive, up $\$ 175.6 \mathrm{~m}$.

The MICEX total capitalization as of 25 May 2015 amounted to $\mathrm{Rb} 27.23$ trillion (38.1\% of GDP), down $0.7 \%$ from the previous month. The capitalization has

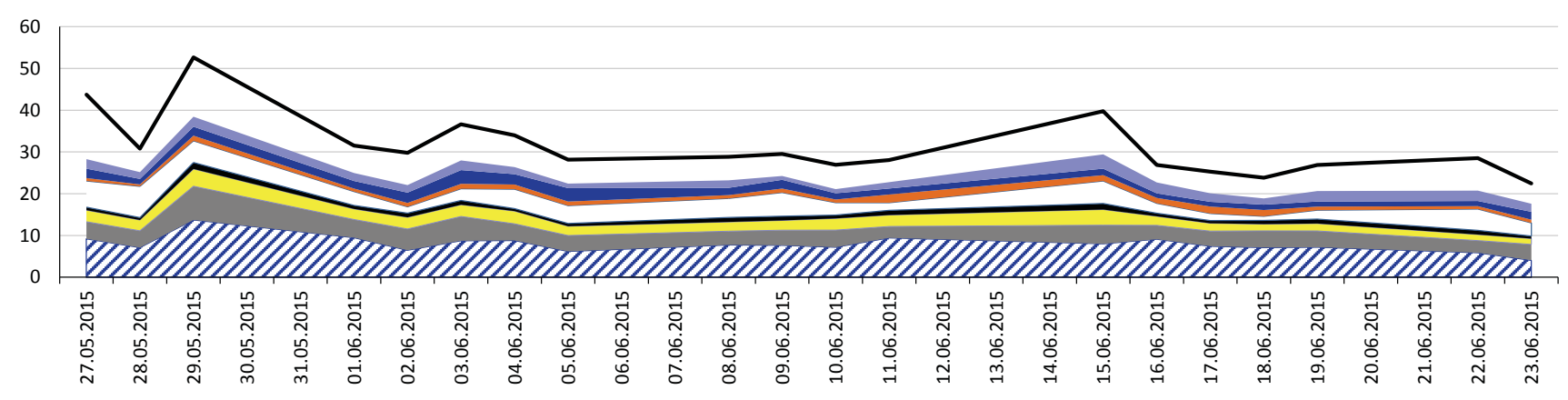

ZaSberbank (common+preferred shares) $\square$ Gazprom $\square$ LUKOIL $\square$ Rosneft $\square$ VTB $\square$ Magnit $\square$ Norilsk Nickel $\square$ Surgutneftegaz (common+pref. shares) $\longrightarrow$ Total turnover

Source: RBK Quote, author's estimates.

Fig. 5. The Moscow Exchange trading volumes structure in the period between 27 May and 25 June 2015 
been shrinking for the second straight month, a decline of $0.9 \%$. The structure of capitalization remained almost the same as that in the previous reporting period. The oil \& gas, metal \& mining, and financial sectors still account for respectively $48 \%, 18 \%$, and $14 \%$ of total capitalization, whereas the rest of the sectors for not more than $6 \%$.

According to the data available at www.preqveca. ru, there was one IPO in the MICEX in Q2 2015. In late April, United Wagon Company (UWC) placed $12.2 \%$ of its shares worth a total of $\mathrm{Rb} 9.03 \mathrm{bn}$. Note that this was the first IPO since November 2013 in the MICEX.

\section{Corporate bond market}

The volume of Russia's domestic corporate bond market (measured by the par value of outstanding ruble-denominated securities including those issued by non-residents) kept growing in June 2015 at a rapid pace. The volume of Russia's domestic corporate bond market (measured by the par value of outstanding ruble-denominated securities including those issued by non-residents) kept growing in June 2015 at a rapid pace. A new all-time high of Rb 7.418.6bn was hit at month's end, outperforming the value seen as of the end of May ${ }^{1}$ by $4.3 \%$. The past period saw substantial changes in the number of both outstanding bond issuances (1127 corporate bond issuances denominated in national currency were registered versus 1086 issuances as of the end of May) and issuers represented in the debt segment (367 issuers against 360 companies). There are already 17 outstanding issuances of dollardenominated bonds of Russian companies (worth a total of more than $\$ 2.4 \mathrm{bn}$ ) and one outstanding JPYdenominated bond issuance.

Investors' activity in the secondary corporate bond market in June subdued but still remained at the average annual level. For instance, the MOEX total trading volume was $\mathrm{Rb} 111.0 \mathrm{bn}$ in the period between 26 May and 22 June 2015 (as compared to Rb 151.7bn in the period between 23 April 2015 and 25 May 2015). There was no substantial change in the number of transactions in the period under review. The number was 22,400 (to compare, 24,000 MOEX transactions were registered in the previous period) $)^{2}$.

The Russian Corporate Bond Market Index (IFXCbonds) in June 2015 kept growing at a slowest rate. The Index increased 1.5 index points (or $0.4 \%$ ) compared to the month-end value in May. However, it was for the first time since January 2015 that the corporate bond average weighted yield saw negative dynamics, increasing from $12.25 \%$ in late May to $12.87 \%$ by the

1 According to the data provided by Rusbonds Information Agency.

2 According to the data provided by Finam Investment Company.

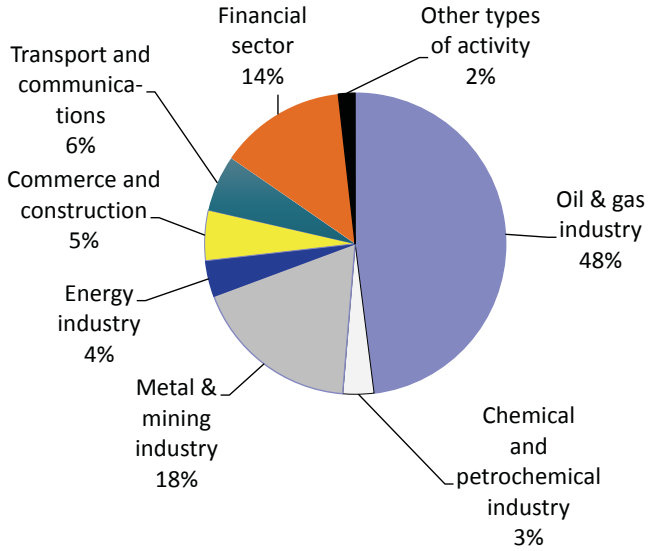

Source: The Moscow Exchange official website, the author's estimates.

Fig. 6. Stock market capitalization structure by type of economic activity as of 25 June 2015

end of the period under review (Fig. 7) 3 $^{3}$ Hence the adverse external effect put a heavier pressure upon the debt market than, for example, the 1 p.p. cut on the $\mathrm{CB}$ key interest rate down to $11.5 \%$ in mid-June. The corporate bond portfolio duration was declining for the third straight month, although its value still remained more than 1.5 times its lows seen earlier in the year. As a result, the duration was 430 days as of the end of June, 55 days less than that as of the end of last month.

Although the market average yield rate increased, the most liquid segment of the corporate bond market saw a moderate decline in the yield of debt securities. The interest rate was cut most (more than 2 p.p.) for bond issuances of predominantly financial institutions such as Alfabank (Joint-Stock Company), VTB Bank (Open Joint-Stock Company), Gazprombank (Joint-Stock Company), Bank ZENIT (Public JointStock Company), Bank Otkritie FC (Public Joint-Stock

3 According to the data provided by Cbonds Information Agency

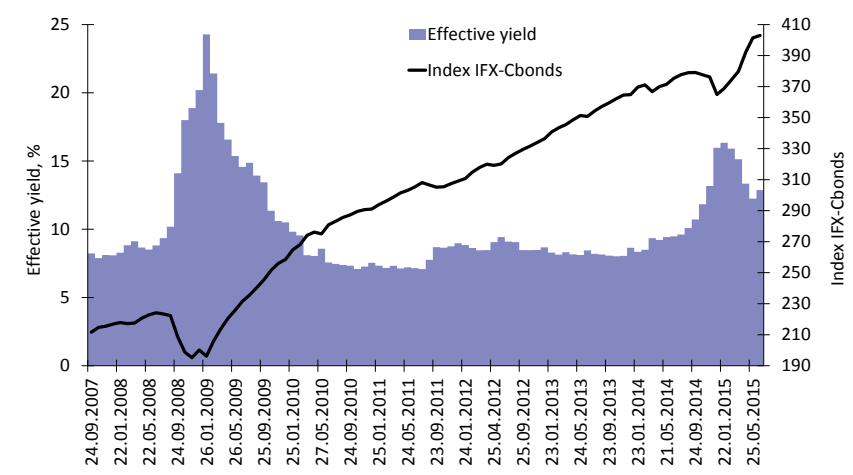

Source: According to the data provided by Cbonds Information Agency.

Fig. 7. The dynamics of Russian corporate bond market index and average weighted yield 
Company), which in the period under review enjoyed a higher demand among investors. At the same time, most of the above listed issuers saw mixed dynamics for the yield on some of their bond issuances. In particular, several bond issuances of Bank ZENIT and Gazprombank saw substantial growth (more than 2 p.p.) in interest rate. Overall, most noticeable downtrend dynamics for the yield on liquid securities was seen in the financial and technological segments (by an average of 0.6 and 0.5 p.p., respectively), whereas the yield on bond issuances of production and energy companies declined by not more than 0.15 p.p. ${ }^{1}$

Issuers' activity in seeking new fundraising remained very low, which can be explained, among other things, by a seasonal downtrend. For instance, as little as seven issuers registered 21 bond issuances with an aggregate par value of $\mathrm{Rb} 53.1 \mathrm{bn}$ in the period between 26 May 2015 and 22 June 2015 (to compare, seven bond series worth a total of $\mathrm{Rb} 39.7 \mathrm{bn}$ were registered in the period between 23 April 2015 and 25 May 2015) $)^{2}$. A single large bond issuer, KAMAZ (Open Joint-Stock Company), accounted for the highest value of bond issuances, registering nine issuances with an aggregate par value of $\mathrm{Rb} 35 \mathrm{bn}$. Most of the rest of bond issuances were first-time issuances. The largest of them were registered by Mortgage Agent Pulsar-2 (Closely-Held Stock Company), Mortgage Agent Vozrozhdeniye-4 (CloselyHeld Stock Company), SPECTR (Limited Liability Company). Half of all of the registered bond issuances were made up of exchange-traded bonds. Further, note that the MICEX SE registered a multicurrency program of Vnesheconombank exchange-traded bonds with a maximum value of $\mathrm{Rb} 300 \mathrm{bn}, \$ 10 \mathrm{bn}$ and $5 \mathrm{bn}$ euros (the par value of a bond is respectively $R b 1,000$, $\$ 1,000$ and 1,000 euros,). The exchange-traded bonds are to be matured within 30 years from the date of commencement of placement of the exchange-traded bonds, and the effective term of the exchange-traded bond program is 10 years from the date of ID-number assignment ${ }^{3}$.

At the same time, investors' activity remained high in both the primary and secondary markets. For instance, 30 issuers placed 42 bond issuances with an aggregate par value of $\mathrm{Rb} 158.6 \mathrm{bn}$ in the period between 26 May 2015 and 22 June 2015 (to compare, 21 bond issuances worth $\mathrm{Rb} 176.7 \mathrm{bn}$ were placed in the period between 23 April 2015 and 25 May 2015) (Fig. 8). Large bond issuances were placed by Magistral Dvukh Stolits (Open Joint-Stock Company), Binbank (Open Joint-Stock Company), Rosseti (Open

1 According to the data provided by Finam Investment Company. 2 According to the data provided by Rusbonds Information Agency.

3 According to the data provided by Finam Investment Company.

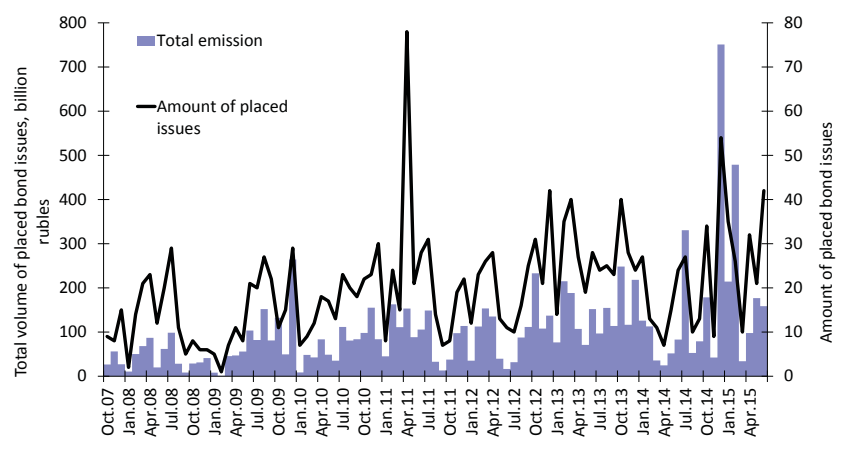

Source: According to the data provided by Rusbonds information agency.

Fig. 8. The dynamics of initial public offerings of corporate bonds denominated in national currency

Joint-Stock Company) ${ }^{4}$. Most of the bonds issued in the period under review were exchange-traded bonds. Many bond issuers managed to raise funds with quite a long maturity: Mortgage Agent Vozrozhdeniye-4 issued bonds with a maturity of almost 33 years, Mortgage Agent Pulsar-2 with a 23-year maturity, Magistral Dvukh Stolits placed two bond issuances with maturities of 15 and 16 years, respectively, eight bond issuers raised funds with a maturity of 10 years.

In late May to June, the Bank of Russia declared void three corporate bond issuances of Russian Railways (Open Joint-Stock Company) on the grounds that not a single security was placed (Open Joint-Stock Company) (two first-time bond series were declared void on the same grounds in the previous period). ${ }^{5}$

In the period between 26 May 2015 and 22 June 2015, six issuers were to redeem their eight bond issuances with an aggregate par value of $\mathrm{Rb} 25.2 \mathrm{bn}$. However, one issuer failed to redeem two of its securities and announced a technical default (one issuer failed to meet its obligations that fell due in the same period last month). Nine corporate bond issuances worth a total of Rb 26.5bn ${ }^{6}$ are due for maturity in July 2015.

The situation with the failure to honor obligations to bondholders still remains complex: an issuer, Utair Finance (Limited Liability Company), declared actual default apart from a few technical defaults ${ }^{7}$ on coupon yield payment and redemption of the par value (only a few technical and actual defaults were declared in the same period last month) ${ }^{8}$.

4 According to the data provided by Rusbonds Information Agency.

5 According to the data provided by the Bank of Russia.

6 According to the data provided by Rusbonds Information Agency.

7 In other words, when a bond issuer is unable to repay to bondholders even during the grace period.

8 According to the data provided by Rusbonds Information Agency. 